\title{
Antibiotics for the treatment of rheumatoid arthritis
}

This article was published in the following Dove Press journal:

International Journal of General Medicine

27 December 2013

Number of times this article has been viewed

\section{Mesut Ogrendik}

Division Physical Therapy and Rheumatology, Nazilli State Hospital, Nazilli, Turkey
Correspondence: Mesut Ogrendik Nazilli State Hospital, Division of Physical Therapy and Rheumatology, Nazilli-Aydin, Turkey

Tel 90256 3I20000

Email neml82@hotmail.com
Abstract: Antibiotic treatment for rheumatoid arthritis (RA) commenced in the 1930s with the use of sulfasalazine. Later, tetracyclines were successfully used for the treatment of RA. In double-blind and randomized studies, levofloxacin and macrolide antibiotics (including clarithromycin and roxithromycin) were also shown to be effective in the treatment of RA. There have been several reports in the literature indicating that periodontal pathogens are a possible cause of RA. Oral bacteria are one possible cause of RA. In this review, we aimed to investigate the effects of different antibiotics in RA treatment.

Keywords: oral bacteria, treatment, disease-modifying antirheumatic drugs, periodontitis

\section{Introduction}

Rheumatoid arthritis (RA) is a systemic inflammatory disease that affects approximately $0.5 \%-1 \%$ of the general population. ${ }^{1}$ Since the $1930 \mathrm{~s}$, RA has been treated with antibiotics, beginning with sulphonamide ${ }^{2}$ and then in the 1960 s, with tetracycline derivatives. McPherson Brown was a proponent of using antibiotics, especially tetracyclines, to treat RA. Based on sporadic evidence in mammals and humans, Brown believed that RA was caused by microorganisms and suggested that long-term antibiotic treatment would change the course of the disease. ${ }^{3}$ During the 1970 s and 1980s, Brown and his colleagues used tetracyclines and other types of antibiotics in the treatment of RA.

In the $1990 \mathrm{~s}$ and in the beginning of the $21 \mathrm{st}$ century, four randomized trials were carried out that investigated the use of minocycline for the treatment of RA. ${ }^{4-7}$ In the last decade, there have been increasing reports indicating that periodontal pathogens might be the cause of RA. ${ }^{8-16}$ This article reviews the use of antibiotics for the treatment of RA.

\section{Sulfasalazine}

Professors Svartz, Willsteadt, and Askelof first produced sulfasalazine (SASP) as a combination of sulphapyridine and 5-aminosalicylic acid in Sweden in the 1930s. ${ }^{2}$ During that time, the sulphonamides were the only valid antibiotics for the treatment of "rheumatoid polyarthritis" (RA). Svartz and her colleagues published their work on the effects of SASP for the treatment of RA in 1948. ${ }^{2}$ However, due to the discovery of corticosteroids in 1949 and the increased interest in gold and penicillamine, SASPs did not become the preferred RA treatment until the 1980s. In a study published in 1980, McConkey et al restored the use of SASPs for the treatment of RA. ${ }^{17}$ 
After intake, SASP is converted into sulphapyridine (SP) and 5-aminosalicylic acid (5-ASA) by the intestinal bacteria in the colon. Thirty percent of SP and the intact SASP molecule are absorbed, but 5-ASA is not, ${ }^{18}$ indicating that SP and SASP are the effective compounds for the treatment of RA. ${ }^{19}$ The benefits of sulfamethoxazole for the treatment of RA further support the hypothesis that $\mathrm{SP}$ is the active reagent in SASP. ${ }^{20}$ Finally, SASP is a type of antibiotic that can be effectively used for the treatment of RA.

In the 1940s, sulphonamides, which are effective in treating various gram-negative and -positive bacteria, were used for the treatment of periodontal diseases. ${ }^{21}$

Two meta-analyses of a number of controlled studies indicated that SASP significantly improved the treatment of $\mathrm{RA}$, in comparison with placebo. ${ }^{22,23}$

The adverse events that occur with SASP include nausea, diarrhea, mucocutaneous reactions, urticaria, photosensitivity, neutropenia, lymphopenia, thrombocytopenia, hepatotoxicity, and the inhibition of spermatogenesis. ${ }^{24}$

\section{Tetracyclines}

Tetracyclines are a group of antibiotics isolated from Streptomyces spp. that are congeners of polycyclic naphthacenecarboxamide. Tetracyclines are protein synthesis inhibitors, inhibiting the binding of aminoacyl-transfer ribonucleic acid (tRNA) to the messenger (m)RNA-ribosome complex. They do so mainly by binding to the $30 \mathrm{~S}$ ribosomal subunit in the mRNA translation complex. ${ }^{25}$

Tetracyclines have a broad spectrum of antibiotic action. They possess some level of bacteriostatic activity against almost all medically relevant aerobic and anaerobic bacterial genera, both gram-positive and gram-negative, with a few exceptions, such as Pseudomonas aeruginosa and Proteus spp. which display intrinsic resistance.

There have been four double-blind, randomized clinical studies published regarding the use of minocycline for the treatment of RA..$^{4-7}$ The first study was carried out in the Netherlands on 80 long-term (disease course $>10$ years) RA patients who had not benefitted from more than one disease-modifying antirheumatic drug (DMARD). In this randomized controlled study, patients were treated with placebo or minocycline ( $200 \mathrm{mg}$ per day) in addition to their previous drug regime, for 6 months. ${ }^{4}$ The second published study was conducted by the Minocycline in RA (MIRA) group. This study was carried out for 1 year and investigated 219 moderate RA patients who did not respond to one or more DMARD. The patients discontinued use of DMARDs during the study. ${ }^{5}$ The other two studies were conducted by the Rheumatoid Arthritis Investigational Network (RAIN). ${ }^{6,7}$ The four trials showed that minocycline is indeed efficacious in the treatment of RA. When the long-term effects were studied, it was found that the minocycline was still effective during the second year of the treatment. ${ }^{7}$

Genetic screening was taken into consideration only in the MIRA study. Interestingly, the better minocycline responders were, among Caucasians, those possessing the shared epitope rather than those not possessing it.

Oral tetracyclines are effective against most periodontal pathogens, and therefore, they are widely used in the treatment of periodontal diseases. ${ }^{26}$ Tetracyclines possess anti-inflammatory characteristics, which are largely independent of their antibacterial activity, and they inhibit certain enzymes, such as collagenase, the host-derived enzyme responsible for the breakdown of collagen, which is released during the inflammatory process. ${ }^{25}$

The adverse events of the tetracyclines include anorexia, nausea, vomiting, dysphagia, photosensitivity, manifest exaggerated sunburn, anogenital lesions with monilial overgrowth, light-headedness, dizziness, vertigo, maculopapular rashes, Stevens-Johnson syndrome, hypersensitivity reactions and urticaria, hemolytic anemia, thrombocytopenia, neutropenia, drug-induced Systemic Lupus Erythematosus (SLE), eosinophilia, and pseudotumor cerebri. ${ }^{25}$

\section{Macrolide antibiotics}

The macrolides are a group of antibiotics whose activity stems from the presence of a macrolide ring, a large macrocyclic lactone ring to which one or more deoxy sugars, usually cladinose and desosamine, may be attached. The lactone rings are usually 14-, 15-, or 16-membered. Macrolides belong to the polyketide class of natural products.

Macrolides are protein synthesis inhibitors. The mechanism of action of macrolides is the inhibition of biosynthesis bacterial protein, and they are thought to do this by preventing peptidyl transferase from adding the peptidyl attached to tRNA to the next amino acid as well as by inhibiting ribosomal translocation. ${ }^{27}$

Macrolide antibiotics are used to treat infections caused by gram-negative anaerobic bacteria. ${ }^{28}$

The first trial with clarithromycin, a macrolide antibiotic, for the treatment of RA was conducted as an open-label study in Italy. ${ }^{29}$ This study of $18 \mathrm{RA}$ patients was carried out for 6 months, and clarithromycin was found to be beneficial for RA treatment. 
In a recent study, Saviola et al compared the efficacy of the addition of clarithromycin to methotrexate and methylprednisolone in active RA. This study showed that the addition of a 4-week clarithromycin cycle was efficacious in inducing the remission of the disease. ${ }^{30}$

In 2006, Ogrendik reported a study of the use of clarithromycin for the treatment of RA. ${ }^{28}$ This was a 6-month, randomized, double blind, placebo-controlled study. A total of 81 patients with early RA were treated with either once-daily oral clarithromycin $(500 \mathrm{mg}$ ) or daily oral placebo. The primary efficacy variable was the percentage of patients who had a $20 \%$ improvement according to the American College of Rheumatology (ACR) criteria (ie, an ACR 20 response) at 6 months. The secondary outcome measures were $50 \%$ improvement and $70 \%$ improvement, according to ACR criteria (an ACR 50 response and an ACR 70 response, respectively). A significantly greater percentage of patients treated with $500 \mathrm{mg}$ clarithromycin met the ACR 20 response at 6 months compared with patients who received placebo (59\% vs 33\%) $(P<0.001)$. A larger percentage of patients treated with $500 \mathrm{mg}$ clarithromycin also achieved ACR 50 responses $(34 \%$ vs $10 \%)(P<0.001)$ and ACR 70 responses (20\% vs 3\%) $(P=0.003)$ compared with patients who received placebo, respectively. The clarithromycin was well tolerated. There were no dose-limiting toxic effects.

In 2009, Ogrendik reported on the use of another macrolide, roxithromycin, for the treatment of early RA. This was a double-blind trial. ${ }^{31}$ Adult patients with early RA who had not previously received DMARDs were enrolled and randomized to receive either once-daily oral roxithromycin (300 mg) or once-daily oral placebo for 3 months. The primary efficacy variable was the percentage of patients who had a 20\% improvement according to ACR criteria at 3 months. The secondary outcome measures were $50 \%$ improvement and $70 \%$ improvement according to ACR criteria. The 28-joint disease activity score (DAS28) was also calculated. The roxithromycin group had 16 patients, and the placebo group had 15 patients. A significantly greater percentage of patients treated with roxithromycin experienced an ACR 20 response at 3 months compared with those who received placebo $(75 \%[\mathrm{n}=12]$ vs $20 \%[\mathrm{n}=3])(P=0.002)$. Greater percentages of patients treated with roxithromycin also achieved ACR 50 responses $(56 \%[n=9]$ vs $7 \%[n=1])(P=0.003)$ and ACR 70 responses $(44 \%[\mathrm{n}=7]$ vs $0 \%)(P=0.004)$ compared with patients who received placebo. At month 3 , the DAS28 response rates were significantly greater with once-daily roxithromycin than with once-daily placebo $(P<0.001)$.
Adverse events were reported for eleven patients $(69 \%)$ in the roxithromycin group and for seven patients (47\%) in the placebo group. The most common $(>5 \%)$ adverse events were nausea, abdominal pain, headache, and dry mouth. There were no dose-limiting toxic effects. One participant in the roxithromycin group withdrew from the study because of severe emesis, while two withdrew from the placebo group because of a lack of efficacy.

In yet another study, Ogrendik and Karagoz used roxithromycin in patients who were known to be resistant to at least one DMARD. ${ }^{32}$ This was a 6-month, randomized, double blind, placebo-controlled trial. The researchers treated 100 active RA patients with either once-daily oral roxithromycin (300 mg) or daily oral placebo for 6 months. The primary efficacy variable was the percentage of patients who had a $20 \%$ improvement according to ACR criteria at 6 months. The secondary outcome measures were $50 \%$ improvement and $70 \%$ improvement according to ACR criteria. A significantly greater percentage of patients treated with roxithromycin met the ACR 20\% improvement criteria at 6 months compared with patients who received placebo (60\% vs $34 \%)(P=0.009)$. Greater percentages of patients treated with roxithromycin also achieved ACR 50 responses $(38 \%$ vs $12 \%)(P=0.003)$ and ACR 70 responses ( $18 \%$ vs $2 \%)(P=0.008)$ compared with patients who received placebo. Roxithromycin was well tolerated, with an overall safety profile similar to that of the placebo.

The most common adverse events with the macrolides are drowsiness and gastrointestinal effects: diarrhea, nausea, abdominal pain, and vomiting. The less common adverse events include headaches; dizziness/motion sickness; rashes; and alteration in the senses of smell and taste, including a metallic taste that lasts the entire time of therapy. Dry mouth has also been reported, albeit less frequently. ${ }^{33}$

\section{Levofloxacin}

Levofloxacin is a broad-spectrum antibiotic of the fluoroquinolone drug class. Levofloxacin ${ }^{34,35}$ is used in the treatment of infections caused by periodontopathic bacteria and facultative anaerobic bacteria. ${ }^{36}$ It functions by inhibiting deoxyribonucleic acid (DNA) gyrase, a type II topoisomerase, and topoisomerase IV, an enzyme necessary to separate replicated DNA, thereby inhibiting cell division. Levofloxacin can also affect mammalian cell replication. In particular, some congeners of this drug family display activity, not only against bacterial topoisomerases but also, against eukaryotic topoisomerases and are toxic to cultured mammalian cells and in vivo tumor models. ${ }^{34,35}$ 
Ogrendik demonstrated the effectiveness of levofloxacin in the treatment of RA. ${ }^{36}$ In this study, the research team randomly assigned 76 patients with persistently active RA, despite at least 6 months of methotrexate therapy at a stable dose of 15 to $25 \mathrm{mg}$ per week, to receive either levofloxacin (500 mg) or placebo orally once daily, while continuing to receive methotrexate. The change in the swollen-joint count and tender-joint count from baseline to 6 months was the primary measure of efficacy. The secondary endpoints included pain, quality of life, the duration of morning stiffness, erythrocyte sedimentation rate, C-reactive protein level, and physician and patient global assessments. The data were analyzed to determine the number of patients meeting ACR criteria for $20 \%, 50 \%$, and $70 \%$ improvement. The levofloxacin plus methotrexate group was associated with the greatest reduction in the number of swollen or tender joints $(P<0.001)$. The levofloxacin plus methotrexate group also had significant improvement in many of the secondary outcome measures $(P<0.001)$. The levofloxacin was well tolerated. There were no dose-limiting toxic effects. In the patients with active RA who received methotrexate, treatment with levofloxacin significantly improved the signs and symptoms of RA.

The most frequently reported adverse events of levofloxacin have included nausea, headache, diarrhea, insomnia, constipation, and dizziness. The serious adverse events that may occur as a result of levofloxacin therapy include irreversible peripheral neuropathy, spontaneous tendon rupture and tendonitis, and QT prolongation/torsades de pointes. ${ }^{37}$

\section{Conclusion}

The studies with various antibiotics confirm the efficacy of these drugs in the treatment of RA. Therefore, it is possible that the pathogen that causes RA is a microorganism (most likely periodontopathic bacteria). ${ }^{38}$

\section{Disclosure}

The author reports no conflicts of interests in this work.

\section{References}

1. Pincus T, O'Dell JR, Kremer JM. Combination therapy with multiple disease-modifying antirheumatic drugs in rheumatoid arthritis: a preventive strategy. Ann Intern Med. 1999;131(10):768-774.

2. Svartz N. The treatment of rheumatic polyarthritis with acid azo compounds. Rheumatism. 1948;4(1):180-185.

3. Brown TM, Clark HW, Bailey JS, Gray CW. A mechanistic approach to treatment of rheumatoid type arthritis naturally occurring in a gorilla. Trans Am Clin Climatol Assoc. 1971;82:227-247.

4. Kloppenburg M, Breedveld FC, Terwiel JP, Mallee C, Dijkmans BA. Minocycline in active rheumatoid arthritis. A double-blind, placebocontrolled trial. Arthritis Rheum. 1994;37(5):629-636.
5. Tilley BC, Alarcón GS, Heyse SP, et al. Minocycline in rheumatoid arthritis. A 48-week, double-blind, placebo-controlled trial. MIRA Trial Group. Ann Intern Med. 1995;122(2):81-89.

6. O'Dell JR, Haire CE, Palmer W, et al. Treatment of early rheumatoid arthritis with minocycline or placebo: results of a randomized, doubleblind, placebo-controlled trial. Arthritis Rheum. 1997;40(5):842-848.

7. O'Dell JR, Blakely KW, Mallek JA, et al. Treatment of early seropositive rheumatoid arthritis: a two-year, double-blind comparison of minocycline and hydroxychloroquine. Arthritis Rheum. 2001;44(10): 2235-2241.

8. Ogrendik M, Kokino S, Ozdemir F, Bird PS, Hamlet S. Serum antibodies to oral anaerobic bacteria in patients with rheumatoid arthritis. Med Gen Med. 2005;7(2):2.

9. Moen K, Brun JG, Valen M, et al. Synovial inflammation in active rheumatoid arthritis and psoriatic arthritis facilitates trapping of a variety of oral bacterial DNAs. Clin Exp Rheumatol. 2006;24(6):656-663.

10. Lundberg K, Kinloch A, Fisher BA, et al. Antibodies to citrullinated alpha-enolase peptide 1 are specific for rheumatoid arthritis and cross-react with bacterial enolase. Arthritis Rheum. 2008;58(10): 3009-3019.

11. Mikuls TR, Payne JB, Reinhardt RA, et al. Antibody responses to Porphyromonas gingivalis (P. gingivalis) in subjects with rheumatoid arthritis and periodontitis. Int Immunopharmacol. 2009;9(1):38-42.

12. Martinez-Martinez RE, Abud-Mendoza C, Patiño-Marin N, RizoRodríguez JC, Little JW, Loyola-Rodríguez JP. Detection of periodontal bacterial DNA in serum and synovial fluid in refractory rheumatoid arthritis patients. J Clin Periodontol. 2009;36(12):1004-1010.

13. Bartold PM, Marino V, Cantley M, Haynes DR. Effect of Porphyromonas gingivalis-induced inflammation on the development of rheumatoid arthritis. J Clin Periodontol. 2010;37(5):405-411.

14. Cantley MD, Haynes DR, Marino V, Bartold PM. Pre-existing periodontitis exacerbates experimental arthritis in a mouse model. J Clin Periodontol. 2011;38(6):532-541.

15. Kinloch AJ, Alzabin S, Brintnell W, et al. Immunization with Porphyromonas gingivalis enolase induces autoimmunity to mammalian $\alpha$-enolase and arthritis in DR4-IE-transgenic mice. Arthritis Rheum. 2011;63(12):3818-3823.

16. Reichert S, Haffner M, Keyßer G, et al. Detection of oral bacterial DNA in synovial fluid. J Clin Periodontol. 2013;40(6):591-598.

17. McConkey B, Amos RS, Durham S, Forster PJ, Hubball S, Walsh L. Sulphasalazine in rheumatoid arthritis. Br Med J. 1980;280(6212): 442-444.

18. Hoult JR. Pharmacological and biochemical actions of sulphasalazine. Drugs. 1986;32 Suppl 1:18-26.

19. Pullar T, Hunter JA, Capell HA. Which component of sulphasalazine is active in rheumatoid arthritis? Br Med J (Clin Res Ed). 1985;290(6481): $1535-1538$.

20. Ash G, Baker R, Rajapakse C, Swinson DR. Study of sulphamethoxazole in rheumatoid arthritis. Br J Rheumatol. 1986;25(3):285-287.

21. Ostrander FD. Vitamins, sulfonamides and antibiotics in periodontal therapy. J Am Dent Assoc. 1948;37(3):279-288.

22. Felson DT, Anderson JJ, Meenan RF. Use of short-term efficacy/ toxicity tradeoffs to select second-line drugs in rheumatoid arthritis. A metaanalysis of published clinical trials. Arthritis Rheum. 1992;35(10):1117-1125.

23. Weinblatt ME, Reda D, Henderson W, et al. Sulfasalazine treatment for rheumatoid arthritis: a metaanalysis of 15 randomized trials. J Rheumatol. 1999;26(10):2123-2130.

24. Scott DL, Dacre JE. Adverse reactions to sulfasalazine: the British experience. J Rheumatol Suppl. 1988;16:17-21.

25. Alarcón GS. Tetracyclines for the treatment of rheumatoid arthritis. Expert Opin Investig Drugs. 2000;9(7):1491-8.

26. Nakao R, Takigawa S, Sugano N, et al. Impact of minocycline ointment for periodontal treatment of oral bacteria. Jpn J Infect Dis. 2011;64(2):156-160.

27. Kwiatkowska B, Maślińska M. Macrolide therapy in chronic inflammatory diseases. Mediators Inflamm. 2012;2012:636157. 
28. Ogrendik M. Effects of clarithromycin in patients with active rheumatoid arthritis. Curr Med Res Opin. 2007;23(3):515-522.

29. Saviola G, Abdi Ali L, Rossini P, et al. Clarithromycin in rheumatoid arthritis patients not responsive to disease-modifying antirheumatic drugs: an open, uncontrolled pilot study. Clin Exp Rheumatol. 2002;20(3):373-378.

30. Saviola G, Abdi-Ali L, Campostrini L, et al. Clarithromycin in rheumatoid arthritis: the addition to methotrexate and low-dose methylprednisolone induces a significant additive value-a 24-month single-blind pilot study. Rheumatol Int. 2013;33(11):2833-2838.

31. Ogrendik M. Efficacy of roxithromycin in adult patients with rheumatoid arthritis who had not received disease-modifying antirheumatic drugs: a 3-month, randomized, double-blind, placebo-controlled trial. Clin Ther. 2009;31(8):1754-1764.

32. Ogrendik M, Karagoz N. Treatment of rheumatoid arthritis with roxithromycin: a randomized trial. Postgrad Med. 2011;123(5): $220-227$.
33. Zuckerman JM, Qamar F, Bono BR. Macrolides, ketolides, and glycylcyclines: azithromycin, clarithromycin, telithromycin, tigecycline. Infect Dis Clin North Am. 2009;23(4):997-1026, ix.

34. Drlica K, Zhao X. DNA gyrase, topoisomerase IV, and the 4-quinolones. Microbiol Mol Biol Rev. 1997;61(3):377-392.

35. Martin SJ, Meyer JM, Chuck SK, Jung R, Messick CR, Pendland SL. Levofloxacin and sparfloxacin: new quinolone antibiotics. Ann Pharmacother. 1998;32(3):320-336.

36. Ogrendik M. Levofloxacin treatment in patients with rheumatoid arthritis receiving methotrexate. South Med J. 2007;100(2): 135-139.

37. Liu HH. Safety profile of the fluoroquinolones: focus on levofloxacin. Drug Saf. 2010;33(5):353-369.

38. Ogrendik M. Rheumatoid arthritis is an autoimmune disease caused by periodontal pathogens. Int J Gen Med. 2013;6:383-386.
International Journal of General Medicine

\section{Publish your work in this journal}

The International Journal of General Medicine is an international peer-reviewed open-access journal that focuses on general and internal medicine, pathogenesis, epidemiology, diagnosis, monitoring and treatment protocols. The journal is characterized by the rapid reporting of reviews, original research and clinical studies across all disease areas.

\section{Dovepress}

A key focus is the elucidation of disease processes and management protocols resulting in improved outcomes for the patient.The manuscript management system is completely online and includes a very quick and fair peer-review system. Visit http://www.dovepress.com/ testimonials.php to read real quotes from published authors.

Submit your manuscript here: http://www.dovepress.com/international-journal-of-general-medicine-journal 